\title{
KOMUNIKASI KELOMPOK DI DALAM RUMAH REHABILITASI KELUARGA KEMBANG CAHAYA
}

\author{
Kuswidianti Dharma Prewitasari ${ }^{1}$, Wiwik Novianti ${ }^{2}$ \\ ${ }^{1}$ Mahasiswa Magister Ilmu Komunikasi, Universitas Jenderal Soedirman \\ ${ }^{2}$ Dosen Fakultas Ilmu Sosial dan Ilmu Politik, Universitas Jenderal Soedirman
}

\begin{abstract}
The increasingly modern like-day era, or commonly called the millennial era, is increasingly worrying about the rise of drug abuse. Many users or addicts come from children who are still underage. This is a serious problem for the Indonesian people, because generations are very easily involved in drug abuse cases and other legal actions. Related to drug problems, one step that needs to be done in handling this case by providing rehabilitation to users or addictions through drug use. The most important drug addicts in the rehabilitation center for the former drug addicts. One of the rehabilitation places in the city of Purwokerto under the name Kembang Cahaya Family Community. The Kembang Cahaya Family Community (Kekaca) is a group of organizations that want to use drug addicts in the healing process. Memory is a rehabilitation house for drug addicts who really want to recover on their own volition and not from solicitation. The pattern of family communication in the Messages is very pronounced. Communication that is like a relationship between a father and his children. In addition, activities in rehabilitation are also filled with a variety of positive activities, both spiritual and non-spiritual in order to be converted into the busyness and emptiness of the junkies in a more positive direction.
\end{abstract}

Keywords: Communication, Community, Drugs, Rehabilitation, Kekaca.

\section{PENDAHULUAN}

Salah satu faktor yang mempengaruhi pembangunan suatu bangsa adalah sumber daya manusia. Di tengah perkembangan berbagai aspek, tidak dapat dipungkiri bahwa berbagai masalah sosial pun kian berkembang. Hal ini menjadi suatu kausalitas yang tidak akan pernah terbantahkan. Pemerintah dan juga masyarakat perlu bersamasama untuk senantiasa meminimalisasi berbagai masalah sosial yang saat ini tengah hadir. Sinergisitas antara pemerintah dan masyarakat diharapkan mampu membangun Negara yang bebas dari masalah sosial masyarakat. Adapun salah satu masalah sosial yang perlu diperhatikan yaitu narkoba.

Narkoba merupakan singkatan dari narkotika dan obat berbahaya. Selain narkoba istilah yang diperkenalkan oleh Departemen Kesehatan Republik Indonesia adalah Napza yang merupakan singkatan dari narkotika, psikotropika dan zat adiktif.
Disadari atau tidak, narkoba sudah lama menjadi masalah sosial bagi negara yang hingga saat ini masih terus berkembang.

*Korespondensi Penulis:

Email: dharmaprewitasari@yahoo.com

Dampaknya bagi Negara adalah berbagai hal mengalami degradasi termasuk degradasi kejiwaan. Selain dampak bagi Negara, adapula dampak individu yang didapatkan dari penggunaan narkobaantara lain, kerusakan sistem syaraf, gangguan pencernaan, gangguan pernafasan, depresi, dan yang paling parah adalah kematian. Maka dari itu, peran pemerintah dan masyarakat dalam menanggulangi narkoba diharapakan mampu mengurangi jumlah pecandu narkoba. Selain mencegah dan menanggulangi narkoba, upaya yang dapat dilakukan untuk mengobati para pecandu adalah dengan melakukan pendampingan khusus atau rehabilitasi.

Menurut Agoeng Noegroho, dkk, pencegahan narkoba memerlukan upaya sedini mungkin, bukan hanya dengan penindakan hukum secara tegas, 
tetapi juga dengan memberikan penyuluhan dan pemberdayaan masyarakat dari pemerintah dan civil society untuk memberikan motivasi, pola pikir pemahaman dan sikap mental bagi masyarakat umumnya, dan para generasi muda supaya bersama menangkal bahaya penyalahgunaan narkoba. Berbagai cara pun dilakukan untuk memberantas tindakan penyalahgunaan narkoba. Baik itu dalam menyelamatkan para korban ataupun pencegahan dini terhadap ancaman bahaya narkoba kepada masyarakat luas melalui seminar dan forum-forum diskusi dengan menjalin koordinasi dengan pihak BNN setempat.

Salah satu kelompok masyarakat yang berperan aktif dalam menangani para korban pecandu narkoba di Banyumas, tepatnya di Purwokerto adalah Komunitas Kembang Cahaya (Kekaca).

Sebagaimana yang tercantum dalam Pasal 104 UU No.35 Tahun 2009 tentang narkotika yang menyatakan bahwa "Masyarakat mempunyai kesempatan yang seluas-luasnya untuk berperan serta membantu pencegahan dan pemberantasan penyalahgunaan dan peredaran gelap narkotika." Maka menjadi hal yang tidak mungkin tidak akan timbulnya inisiatif sekelompok masyarakat dalam upaya mendukung BNN mewujudkan visi Indonesia 2015 Bebas Narkoba.

Menurut Dina Novitasari, Rehabilitasi terhadap pemakai atau pecandu penyalahgunaan narkoba dilakukan sebagai upaya memulihkan kembali kondisi dan merupakan suatu upaya dalam memberikan perlindungan hukum terhadap pemakai atau pecandu. Alternatif pemidanaan dengan rehabilitas juga mampu melindungi masa depan generasi muda yang bisa juga disebut sebagai korban penyalahgunaan narkoba agar tidak semakin terjerumus.

Rehabilitasi menurut Lulu Ul Jannah dalam UU No 35 Tahun 2009 tentang narkotika, terdapat setidaknya dua jenis rehabilitasi, antara lain rehabilitasi medis dan rehabilitasi non-medis (sosial). Pasal 1 butir 16 UU No 35 Tahun 2009 menyatakan bahwa: Rehabilitasi medis adalah suatu proses kegiatan pengobatan secara terpadu untuk membebaskan pecandu dari ketergantungan narkotika. Pasal 1 butir 17 UU No 3 Tahun 2009 menyatakan bahwa: Rehabilitasi non-medis (sosial) adalah suatu proses kegiatan pemulihan secara terpadu, baik fisik, mental, maupun sosial, agar bekas pecandu narkotika dapat kembali melaksanakan fungsi dalam kehidupan masyarakat.

Selain itu dalam masa rehabilitasi, hal yang paling penting dilakukan adalah dengan memberikan pemahaman mengenai konsep diri terhadap para korban penyalahgunaan narkoba. Dengan memberikan pengetahuan dan pemahaman mengenai konsep diri, nantinya diharapkan dapat membentuk konsep pada diri para korban penyalahgunaan narkoba ke arah yang lebih positif.

Menurut Megiyana Djoharwati, Konsep diri adalah bagian diri yang dapat mempengaruhi setiap aspek pengalaman baik itu perasaan, persepsi dan tingkah laku untuk menilai diri mereka sendiri.

Dengan kata lain, konsep diri yang baik akan terbentuk melalui lingkungan yang dapat memberikan efek positif, sebaliknya jika konsep diri terbentuk dari lingkungan yang memberikan efek negatif pada diri, maka yang akan terbentuk dalam diri seseorang tersebut adalah negatif.

Seperti contohnya dalam kasus narkoba ini, lingkungan pertemanan menjadi faktor paling penting sekaligus penentu dalam pembentukan konsep diri pada diri seseorang. Jika seseorang berada di lingkungan pertemanan yang terbiasa mengkonsumsi obat-obatan terlarang atau narkoba, maka nantinya seseorang tersebut akan mengikuti kebiasaan tersebut tanpa memikirkan dampak apa yang akan diterimanya setelah mengkonsumsi barang terlarang tersebut.

Komunikasi merupakan proses penyampaian pesan oleh komunikator kepada komunikan. Menurut Effendy (2009;32), Komunikasi merupakan proses penyampaian suatu pesan dalam bentuk lambang bermakna sebagai pikiran dan perasaan berupa ide, informasi, kepercayaan, harapan, himbauan dan sebagai panduan yang dilakukan oleh seseorang kepada orang lain, baik langsung secara tatap muka maupun tidak langsung melalui media, dengan tujuan mengubah sikap, pandangan atau perilaku. Dari pengertian tersebut, jelas bahwa komunikasi melibatkan sejumlah orang dimana seseorang menyatakan sesuatu kepada orang lain, karena hanya kepada manusia- 
manusia yang bermasyarakat komunikasi dapat terjadi. Masyarakat terbentuk dari paling sedikit dua orang yang saling berhubungan dengan komunikasi sebagai penjalinnya.

Sedangkan pengertian Kelompok menurut Joseph De Vito (1997) kelompok adalah sekumpulan individu yang berhubungan satu sama lain yang memiliki tujuan bersama dan adanya kelompok atau struktur diantara mereka. Di dalam kelompok dikembangkan norma-norma yang dianggap sebagai dasar berperilaku anggotanya.

Komunikasi Kelompok menurut Little John (1989), adalah komunikasi yang fokus pembahasannya pada interaksi diantara orangorang yang ada dalam kelompok-kelompok kecil. Komunikasi kelompok juga melibatkan komunikasi antar pribadi. Adapun teori komunikasi kelompok membahas tentang dinamika kelompok, efisiensi, dan efektivitas penyampaian informasi dalam kelompok, pola dan bentuk interaksi, serta pembuatan keputusan.

Menurut Dwi Afrimetty Timoera \& Agus Martono, dalam menentukan apakah rehabilitasi dan pola pembinaan terhadap pecandu narkotika dapat dikatakan efektif atau tidak, hal ini sangat dipengaruhi oleh beberapa faktor. Faktor tersebut ada yang berasal dari dalam diri (faktor internal) dan ada yang berasal dari luat (faktor eksternal). Faktor yang berasal dari dalam yang mempengaruhi efektivitas rehabilitasi dan pola pembinaan terhadap pecandu narkotika terdiri dari berbagai hal, antara lain:

1) Kemauan yang kuat dari dalam diri residen itu sendiri untuk sembuh dan terbebas dari ketergantungan terhadap narkoba.

2) Pola pikir residen itu sendiri terhadap efek atau dampak buruk yang ditimbulkan jika masih menggunakan narkoba.

3) Perubahan perilaku residen selama menjalani proses rehabilitasi dan pola pembinaan.

Faktor yang berasal dari dalam ini sangat memiliki pengaruh yang besar dalam kesembuhan para korban penyalahgunaan narkoba serta efektivitas rehabilitasi dan pola pembinaan yang dilakukan. Selain faktor dari dalam, adapula faktor dari luar (faktor eksternal) yang juga berpengaruh besar dan dapat menentukan efektivitas rehabilitasi dan pola pembinaan tersebut. Adapun faktor yang berasal dari luar antara lain:

1) Dukungan penuh dari orang-orang terdekat, seperti teman-teman, pasangan, dan terutama orang tua atau wali.

2) Lingkungan tempat residen (pecandu) bergaul atau menjalani aktivitas sehari-hari sangat menentukan apakah residen akan kembali lagi menjadi pecandu atau tidak. Hal yang sangat menjadi penentu atau faktor utama terhadap dari yang sudah disebutkan diatas adalah lingkungan tempat para korban penyalahgunaan narkoba bergaul atau menjalani aktivitas sehari-hari.

Jika setelah sembuh, korban kembali ke lingkungan atau teman-teman yang membuatnya terkena pengaruh untuk menggunakan narkoba, kemungkinan besar akan membuat korban terpengaruh kembali dan menggunakan narkoba lagi, sehingga efektivitas rehabilitasi dan pola pembinaan terhadap pecandu narkoba akan buruk.

\section{METODE PENELITIAN}

Penelitian ini menggunakan pendekatan kualitatif deskriptif. Menurut Danim, terdapat ciri dalam penelitian kualitatif, yaitu:

1. Penelitian kualitatif memiliki setting alami sebagai sumber data langsung.

2. Penelitian kualitatif bersifat deskriptif.

3. Penelitian kualitatif lebih menekankan proses kerja.

4. Penelitian kualitatif cenderung menggunakan pendekatan induktif.

5. Penelitian kualitatif memberi titik tekan pada makna.

Adapun data yang diperoleh dalam penelitian ini yaitu menggunakan observasi, wawancara mendalam dan penelaahan dokumen. Observasi disini dilakukan dengan mengamati kegiatan yang dilakukan di kelompok atau komunitas Keluarga Kembang Cahaya. Wawancara mendalam dilakukan kepada ketua komunitas kembang cahaya yaitu Bapak Surya Esa dan Roni selaku anggota pengurus kelompok atau komunitas. 
Wawancara mendalam dilakukan dengan tujan untuk menggali informasi mendalam mengenai segala hal yang berkaitan dengan kelompok Keluarga Kembang Cahaya (KeKaCa) mulai dari profil kelompok hingga proses pendampingan yang dilakukan. Sedangkan penelaahan dokumen yang dilakukan disini adalah dengan menelaah dokumen pendirian badan hukum kelompok Keluarga Kembang Cahaya.

\section{HASIL DAN PEMBAHASAN}

\section{a. Profil Keluarga Kembang cahaya}

Keluarga Kembang Cahaya atau biasa disebut dengan Kekaca, merupakan rumah bagi para pecandu narkoba yang setidaknya memberikan sedikit angin segar ditengah meningkatknya pengguna narkoba di Indonesia. Diinisiasi oleh Bapak Surya Esa, Kekaca menjadi rumah rehabilitasi atau pendampingan bagi para pencandu narkoba yang benar-benar ingin sembuh atas dasar kemauan sendiri dan bukan dari ajakan orang lain.

Keluarga Kembang Cahaya lahir pada 26 Juni 2013 berawal dari kegiatan Peringatan Hari Anti Narkotika Internasional (HANI) 2013 yang diselenggarakan oleh Badan Narkotika Kabupaten Banyumas melalui acara aksi simpatik bersama dengan LSM Ormas, OKP, dan UKM.

Komunitas Kembang Cahaya (Kekaca) merupakan salah satu contoh kelompok yang memberikan fokus pendampingan untuk para pecandu narkoba yang ingin sembuh dan berada di Kabupaten Banyumas. Karena berdasarkan faktanya tingkat pecandu narkoba yang ada di Indonesia masih cukup tinggi.

Sebagaimana kita ketahui Komunitas ini merupakan kelompok yang ingin membantu para pecandu narkoba dalam proses rehabilitasi atau pendampingan. Sebagian besar anggota-anggota yang tergabung dalam Rumah Keluarga Kembang Cahaya berasal dari banyumas. Akan tetapi ada juga yang berasal dari luar Banyumas, seperti Lampung dan Medan. Anggota yang tergabung juga kurang lebih sekitar 200 orang dan rata-rata yang tergabung adalah yang orang-orang yang berusia 18-40 tahun. Biasanya yang berusia 40 tahun adalah sebagai pengedar narkoba. Para pecandu yang ingin masuk dalam komunitas ini harus yang memiliki niat dan keinginan dari diri sendiri untuk sembuh dan datang dengan wali atau dengan orang tuanya.

Menurut hasil wawancara bersama dengan Bapak Surya Esa, jika mereka ingin benar-benar memiliki keinginan kuat untuk berubah, "mereka harus datang dengan Wali yang menjadi penanggung jawab". Karena, disadari ataupun tidak, peran wali/orang tua turut ikut andil dalam upaya penyembuhan. Setelah sepakat, kedua belah pihak membuat pernyataan tertulis, membuat pernyataan verbal yang direkam yang menyatakan keseriusan untuk sembuh. Terakhir, difoto dan resmi memperoleh kartu anggota keluarga sekaligus resmi menjalani rehabilitasi.

Dalam Komunitas Kembang Cahaya (Kekaca) ini para pecandu narkoba yang tergabung dalam Rumah Keluarga Kembang Cahaya (Kekaca) melakukan banyak kegiatan ketika berkumpul seperti bermain musik, melukis, penyuluhan, teater, menyablon. Kegiatan-kegiatan yang dilakukan adalah kegiatan yang bersifat positif, sebagai cara untuk merangkul anak-anak atau "korban" yang menggunakan narkotika selain direhabilitasi.

Wujud yang berbeda yang menjadi jembatan BNK Banyumas berkolaborasi dengan masyarakat yaitu Parade Musik 8 Jam Anti Narkoba yang mewarnai kegiatan tahunan ini. Ada bebarapa orang dari grup band yang tampil datang kepada menemui Surya Esa, yang mempunyai keinginan untuk terbebas atau sembuh dari ketergantungan obat. Melihat hal itu, BNK Banyumas melakukan fasilitasi di suatu tempat yaitu Wisma Indria Prana Baturraden selama 5 (lima) hari untuk menyelenggarakan kegiatan Narcotics Annonimous (NA) yang berlangsung dari tanggal 20 Juli s.d 26 Juli 2013 dibantu oleh dokter psikiater dari RSUD Banyumas (dr. Hilma Paramitha).

Berawal dari kegiatan itu, maka lahirlah Keluarga Kembang Cahaya yang anggotanya adalah anak-anak yang ikut acara tersebut di atas dan menyatakan ingin sembuh dari ketergantungan obat. Sehingga, pada tanggal 26 Juli itu juga lahirlah kesepakatan bersama Keluarga Kembang 
Cahaya yang bertujuan untuk membantu anakanak tersebut keluar atau sembuh dari ketergantungan obat dan mencarikan solusi untuk kembalinya anak-anak tersebut menjadi manusia seutuhnya atau manusia mandiri.

$\begin{array}{cccc}\text { Keluarga } & \text { Kembang } & \text { Cahaya } & \text { selanjutnya } \\ \text { mendapatkan } & \text { dukungan } & \text { dari } & \text { Pemerintah }\end{array}$
Kabupaten Banyumas berupa tempat untuk berekspresi. Sebuah bangunan rumah yang beralamat di Jalan Beringin No.3 Purwokerto Utara. Selanjutnya rumah tersebut menjadi pusat atau sentra aktivitas Keluarga Kembang Cahaya.

Kekaca sendiri mempunyai rencana untuk melaksanakan atau memberikan kegiatan melayani perbaikan atau servis alat pendingin, servis motor, membuka salon, pelatihan musik dan lain lain. Sederhananya, Kekaca telah melakukan apa yang bisa dan dianggap benar. Akan tetapi di sisi lain, Kekaca pun membutuhkan bantuan dari berbagai pihak utuk mewujudkan cita-cita bangsa Indonesia yang terbebas dari narkoba pada umumnya dan Kabupaten Banyumas pada khususnya.

Menurut Nawangsih, Putri Rismala Sari ${ }^{7)}$ dikatakan bahwa rehabilitasi merupakan salah satu cara terbaik untuk mengatasi penyalahgunaan narkoba. Masuknya pengguna narkoba ke panti rehabilitasi memberi konsekuensi pentingnya melakukan penyesuaian diri.

Memasuki masa rehabilitasi, yang paling utama akan direhabilitasi secara kejiwaan/medis oleh dokter. Setelah rehabilitasi secara medis, selanjutnya berdasarkan hasil wawancara dengan Bapak Surya Esa dan Ronny selaku anggota komunitas bahwa "rehabilitasi sosial dilakukan dengan menyalurkan tenaga mereka berbagai keahlian diantaranya pada jasa pelayanan servis alat-alat elektronik, servis motor, salon kecantikan dan pelatihan/jasa rental computer, juga les musik. Seluruh kegiatan ini ditujukan bagi masa depan mereka untuk kembali menjadi manusia seutuhnya".

Pada tahap inilah, proses rehabilitasi sosial para Junkie tengah berproses. Bahwa sesungguhnya keberadaan mereka bisa memiliki arti bagi masyarakat sekitar. Bahwa tenaga mereka dibutuhkan. Keahlian mereka diandalkan. Dan pengakuan-pengakuan lain yang pada akhirnya mampu menumbuhkan rasa kemanusiaan mereka sebagai makhluk sosial. Berbeda dengan keadaan mereka saat menjadi pecandu. Aktivitas yang dilakukan hanya demi memuaskan keinginan diri sendiri. Jangankan dengan masyarakat sekitar, dengan keluarga saja mereka menarik diri dan menjauh. Karenanya Keluarga Kembang Cahaya menerapkan semboyan "Bertegur Sapa Untuk Saling Mengasihi.

Yang menjadi ciri khas dan menarik pada Kekaca yaitu dengan tidak mengajak para junkie, akan tetapi harus berdasarkan keinginannya sendiri. Dalam wawancara yang kami lakukan, Bapak Surya Esa yang merupakan bapak dari para junkie di Kekaca mengatakan, tidak pernah dan tidak akan mengajak para pecandu untuk mau datang secara terpaksa mencurahkan isi hatinya hanya demi perubahan hidup yang sesungguhnya mereka inginkan. Yakni hidup tenang dan damai, bebas dari narkoba. Tetapi, dengan kesan positif para junkie di Kekaca menjalani pola hidup sehat, melayani masyarakat dengan keterampilan yang telah ditekuni, serta menyumbangkan tenaga secara sukarela melalui misi kemanusiaan seperti membantu korban narkoba yang ingin sembuh. Semua itu menyentuh nurani siapapun yang memandang dan merasakan manfaat keberadaan rumah rehabilitasi Kembang Cahaya.

\section{b. Pola Komunikasi}

Selain pola kekeluargaan di Kekaca yang sangat terasa, kelompok ini membangun komunikasi seperti layaknya perlakukan seorang bapak kepada anaknya yaitu yang rela melakukan apa saja hanya untuk menyembuhkan anak-anaknya serta untuk melihat anak-anaknya sukses di masa depan kelak. Kasih sayang terjalin satu sama lain, terlebih bagi seorang bapak. Bahkan, menurut pengakuan Bapak Surya Esa, beliau seringkali menangani anakanaknya yang tertimpa masalah seperti maling helm, masalah di tempat bekerjanya, dsb. Dan beliau akan datang serta siap membantu pada waktu kapanpun. Oleh karena itu, berdasarkan dengan pola komunikasi yang disebutkan di atas maka dalam membangun saluran komunikasi untuk membangun rasa kekeluargaan dalam Kekaca, Bapak Surya Esa melakukan beberapa 
komunikasi yang disalurkan kedalam beberapa saluran, seperti melalui penggunaan WhatsApp.

Melalui group WhatsApp yang tergabung antar satu sama lain, Bapak Surya Esa memiliki filterisasi tersendiri dalam pengelolaannya, sehingga tidak semua junkie mampu bertemu di dalam satu grup yang sama. Para junkie mempunyai tahapan yang harus dilalui upaya berkembang menjadi lebih baik hingga benarbenar terlepas dari candu narkoba.

Selain itu, berbagai perkumpulan untuk menyelenggarakan suatu agenda pun sering dilakukan. Hal ini bertujuan untuk mengalihkan kesibukan dan kekosongan jiwa para junkie ke arah positif, salah satunya diikutsertakan ke dalam kepanitiaan suatu agenda. Selain mengalihkan kesibukan ke arah positif, pun untuk membangun solidaritas serta kerjasama antar sesama manusia. Agar kelak, para junkie tidak lagi canggung disaat berbaur dengan masyarakat setempat.

Saluran lain yang rutin dilakukan yaitu melalui perkumpulan rutin di basecamp pada dini hari, tepatnya pukul 01:00. Meski dilaksanakan pada dini hari, perkumpulan ini dinilai penting sebagai saluran komunikasi untuk senantiasa saling curhat satu sama lain membahas berbagai hal.

Perkumpulan pada dini hari ini dikarenakan oleh banyaknya para junkie yang sudah bekerja, akan tetapi waktu pulangnya pada malam hari. Dalam upaya rehabilitasi ini, selain dalam penanganan kejiwaan, Kekaca pun berupaya agar para junkie kelak mampu berbaur dan diterima oleh masyarakat.

Maka dari itu, Kekaca melakukan berbagai diskusi dan kegiatan-kegiatan positif lain untuk membuat para junkie sibuk, diantaranya dengan cara penggalian hobi, seperti bermusik, salon, dsb. Terbukti, grup band yang dimiliki Kekaca saat ini akan melakukan rekaman bersama label musik Nagaswara di Jakarta. Tidak dapat dipungkiri, sebagian dari anggota Kekaca pun, ada yang ingin bekerja untuk mencari uang. Maka dari itu, Bapak Surya Esa pun menawarkan beberapa pekerjaan untuk senantiasa ditekuni.

\section{PENUTUP}

Upaya Kekaca untuk merangkul para pecandu narkoba, tentu membutuhkan pola komunikasi yang tidak mudah. Komunikasi menjadi hal utama untuk memahami dan menghubungkan antar sesama pecandu, terlebih ini berkaitan erat dengan mental kejiwaan. Akan tetapi, hadirnya Kekaca di tengah masyarakat, setidaknya menjadi keluarga yang memberikan rasa aman bagi sesama pecandu yang mungkin sudah pasrah terhadap kehidupannya. Selain itu, hadirnya Kekaca pun sebagai upaya memperoleh status serta harga diri para pecandu untuk senantiasa bangkit dari keterpurukan. Pun tidak dapat dipungkiri, Kekaca menjadi kekuatan tersendiri disaat para pecandu narkoba dikucilkan dan dijauhi oleh masyarakat. Pada konteks ini, Kekaca menjadi rumah peneduh yang memberikan dorongan positif bagi sesama pecandu narkoba untuk tidak menyalahkan diri sendiri dan masa lalunya melalui rehabilitasi jiwa dan sosial.

Dari keseluruhan aktivitas yang dilakukan oleh Kekaca, setidaknya sudah mencakup kedalam tiga tipe pencegahan penyalahgunaan narkoba. Diawali dari, pencegahan Primer, yakni melakukan upaya pencegahan sejak dini agar orang tidak menyalahgunakan narkoba.

Keberadaan rumah rehabilitasi Kekaca secara tidak langsung akan menimbulkan image di masyarakat setempat mengenai pentingnya menjauhkan diri dari obat-obatan terlarang. Bila kita tidak mempunyai pertahanan yang kokoh terhadap bahaya laten narkoba, maka yang terjadi adalah sebagaimana pengalaman buruk para penghuni rumah Kekaca. Pengalaman saat terjerat dalam lingkaran narkoba, cukuplah dirasakan oleh mereka saja. Bagi yang belum masuk ke dalamnya, akan lebih baik bila tidak mencoba. Karena sekali mencoba pasti terbuai, selanjutnya akan ketagihan hingga sulit dihilangkan.

Kemudian, pencegahan sekunder, yakni upaya menyadarkan, memberi terapi atau mengarahkan pola hidup sehat bagi mereka yang sudah mulai menginisiasi penyalahgunaan narkoba. Tindakan ini dilakukan agar si korban tidak berkembang menjadi pecandu. Maraknya peredaran gelap narkoba ke berbagai lapisan masyarakat tentu akan mendobrak pertahanan sebagian orang yang 
terkena ranjau kenikmatan semu narkoba. Karena para pengedar hanya memikirkan keuntungan besar dari hasil penjualan, tanpa pernah memikirkan dampak negatif dari penyalahgunaan narkoba.

Terakhir, pencegahan tertiari, yakni tindakan rehabilitasi bagi mereka yang sudah berstatus sebagai pecandu, agar dapat pulih dari ketergantungan dan bisa kembali diterima keluarga serta mampu bersosialisasi di lingkungan masyarakat. Pada langkah ini, setidaknya Kekaca sudah membuktikan. Dengan keberadaannya yang baru berdiri beberapa bulan saja telah mampu secara perlahan meraih simpati para pecandu untuk mau direhabilitasi.

\section{DAFTAR PUSTAKA}

Agoeng, Adhi, dkk, "Pendekatan Spritual Dan Herbal Sebagai Alternatif Rehabilitasi Non Medis Bagi Pecandu Narkoba", Jurnal Hasil-Hasil Penelitian, Volume 13, Nomor 2 (November, 2018).

Arnold, Hugh J, Daniel C Feldman. 1986. Individual in Organizations. New York: McGraw Hill, Series in Management.

Danim, Sudarwan. 2002. Menjadi Peneliti Kualitatif. Bandung: Pustaka Setia.

Darimis, "Pemulihan Kondisi Remaja Korban Narkoba Melalui Pendekatan Konseling", Jurnal Ta'dib, Volume 13, No.1 (Juni 2010).

Devito, Joseph. 1997. Komunikasi Antarmanusia. Prifessional Books: Jakarta.
Dina, "Rehabilitasi Terhadap Anak Korban Penyalahgunaan Narkoba", Jurnal Hukum Khaira Ummah, Vol. 12, No. 4 (4 Desember 2017).

Djoharwati, Megiyana. 2017. Konsep Diri Remaja Putra Selama Proses Rehabilitasi di IPWL (Institusi Penerima Wajib Lapor) Yayasan Pendidikan Islam Nurul Ichsan Al-Islami Pondok Pesantren dan Panti Rehabilitasi Narkoba Purbalingga. Purwokerto: Institut Agama Islam Negeri.

Dwi, Agus, "Efektivitas Rehabilitasi dan Pola Pembinaan Terhadap Pecandu Narkotika di Balai Besar Rehabilitasi Badan Narkotika Nasional Indonesia LIDO Bogor", Jurnal Ilmiah Mimbar Demokrasi, Volume 16, Nomor 1 (Oktober 2016).

Effendy, Onong Uchjana. 2009. Komunikasi Teori dan Praktek. Bandung: PT. Remaja Rosdakarya.

Little John, S W. Foss, K A. 2009. Jakarta: Salemba Humanika.

Muhhammad, Arni. 1995. Komunikasi Kelompok. Jakarta: Bumi Aksara.

Nawangsih, Putri Rismala Sari, "Stres Pada Mantan Pengguna Narkoba Yang Menjalani Rehabilitasi”, Jurnal Psikologi Undip, Vol.15, No.2, (Oktober 2016): 99-107.

Ul Jannah, Lulu. 2018. Rehabilitasi Bagi Penyalahguna Narkotika di Badan Narkotika Nasional Kabupaten Banyumas. Purwokerto: Institut Agama Islam Negeri. 